\title{
EFFECT OF IRRADIATION ON FOOD SAFETY AND QUALITY
}

\author{
Mila Arapcheska ${ }^{1 *}$, Hristina Spasevska ${ }^{2}$, Margarita Ginovska ${ }^{2}$ \\ 1"St. Kliment Ohridski” University, Faculty of Biotechnical Sciences - Bitola, R. of North Macedonia \\ 2"Ss. Cyril and Methodius" University, Faculty of Electrical Engineering and Information Technologies - Skopje, \\ R. of North Macedonia
}

\section{Current Trends in}

Natural Sciences

\begin{abstract}
Numerous processing techniques have been developed to control food spoilage and raise food safety. The traditional methods of preservation include: pasteurization, canning, freezing, refrigeration and use of chemical preservatives. Food irradiation is non-thermal food preservation process. It is a treatment of food exposition on an amount of energy in the form of speed particles or rays. Depending on absorbed radiation dose, various effects can be achieved, resulting in reduced storage losses, extended shelf life, improved microbiological and parasitological safety of foods. The potential application of ionizing radiation in food processing is based mainly on the fact that ionizing radiations damage very effectively the DNA molecules. The application is very diverse, from inhibition of sprouting of tubers and bulbs, to production of commercially sterile food products. At the same time, irradiation-induced chemical changes in food are minimal. Irradiation does not cause any significant loss of macronutrients. Proteins, fats and carbohydrates undergo minimal modifications in nutritional value, which are less significant compared with traditional methods of food preservation. Irradiation offers a potential to enhance microbiological safety and quality of food through extension of its shelf life. The aim of this review paper is to give an overview of the effects of ionizing radiation on microbial contaminants and nutritional characteristics of food. In the paper, the basic concepts of food irradiation, mode of action on microbes and the effects of ionizing radiation on nutritional quality of irradiated food are summarized.
\end{abstract}

Keywords: food irradiation, food safety, food quality.

\section{INTRODUCTION}

Food safety is a crucial issue for human health. Foodborne diseases present a widespread threat to human health and they are an important cause of reduced economic productivity even in advanced countries which have modern food processing and distribution systems (Mostafavi et al., 2010; Mostafavi et al., 2012).

Contamination of foods, especially with microorganisms, particularly pathogenic non-sporeforming bacteria, parasitic helminths and protozoa is one of the most significant public health problems all over the world. Elimination or reduction of foodborne pathogens in foods is especially important to people with compromised immune system, such as the elderly, AIDS patients and other people with diseases of the immune system (Farkas, 1998).

Numerous techniques have been developed to control food spoilage, increase safety and satisfy consumer demands regarding the nutritional and sensory characteristics of food, absence of chemical preservatives, price, etc. The preservation techniques extend the shelf life of foods while maintaining their safety and organoleptic properties. These techniques involve the procedures, 


\section{Current Trends in Natural Sciences}

Vol. 9, Issue 18, pp. 100-106, 2020

https://doi.org/10.47068/ctns.2020.v9i18.014

Current Trends in Natural Sciences (on-line)

ISSN: 2284-953X

Current Trends in Natural Sciences (CD-Rom)

ISSN: 2284-9521

ISSN-L: 2284-9521

ISSN-L: 2284-9521

which are taken to maintain foods with the desired properties for a desired time. Throughout the centuries, the food preservation techniques have been improving with the increase of scientific development (Rahman, 2012; Ahmad Shah et al., 2014).

The traditional methods of food preservation include: pasteurization, drying, canning, freezing, refrigeration, chemical treatment and so on. All of these methods have both beneficial and adverse effects on food quality. On the other hand, there is an increasing demand for nutritious, fresh-like food products with high organoleptic attributes, improved safety and prolonged shelf life (Junqueira-Goncalves et al., 2011; Ahmad Shah et al., 2014).

This paper aims to give an overview of the application of ionizing irradiation in food processing with emphasis on the effects on microbial contaminants and nutritional characteristics of food.

\section{FOOD IRRADIATION}

Food irradiation is non-thermal food preservation process. It is a treatment of food exposition on an amount of energy in the form of speed particles or rays. Depending on absorbed radiation dose, various effects can be achieved, resulting in reduced storage losses, extended shelf life and/or improved microbiological and parasitological safety of foods (Farkas, 2006). The food irradiated with ionizing radiation is named as "irradiated food" (Kobayash, 2018).

Food irradiation is a physical process in which food commodities, bulk or pre-packaged are exposed to controlled doses of energy of ionizing radiation such as gamma rays, X-rays or electron beams. Irradiation has direct and indirect effect on living organisms such as: microorganisms, insects and parasites, which result in its preservative effect (Farkas, 1998; Molins, 2001; Farkas, 2006).

Although regarded as a new technology by some individuals, food irradiation has about 100 years of history and it is developed as scientifically established technology and safe food process during the second half of the $X^{\text {th }}$ century (Pillai, 2004; Farkas and Mohacsi-Farkas, 2011).

Food irradiation technology is being used in an increasing number of countries for decontamination and/or sterilization of dehydrated vegetables, fruits, meats, poultry, fish and seafood to improve product safety and shelf life (Ahmad Shah et al., 2014).

For the treatment of food, the following ionizing radiations have been approved: gamma radiation from cobalt-60 $\left({ }^{60} \mathrm{Co}\right)$ with maximum energy of 1.17 and $1.33 \mathrm{MeV}$, and cesium-137 $\left({ }^{137} \mathrm{Cs}\right)$ with energy of $0.662 \mathrm{MeV}$; accelerated electrons (forming electron beams) with a maximum energy of $10 \mathrm{MeV}$ and $\mathrm{X}$ rays with a maximum energy of $5 \mathrm{MeV}$ (Codex Alimentarius, FAO/WHO, General Standard for Irradiated Foods, 2003).

Table 1. Characteristics of the different types of ionizing radiation (International Atomic Energy Agency, Manual of Good Practice in Food Irradiation: Sanitary, Phytosanitary and Other Applications, 2015)

\begin{tabular}{|l|l|c|c|}
\hline \multicolumn{2}{|c|}{ Radioisotope ${ }^{60} \mathrm{Co}$ or ${ }^{37} \mathrm{Cs}$} & \multicolumn{2}{c|}{ Machines using electricity } \\
\hline \multirow{3}{*}{ Type of radiation } & \multicolumn{1}{|c|}{ Gamma } & Accelerated electrons & X rays \\
\hline \multirow{3}{*}{ Emission of radiation } & Cannot be switched off & Can be switched off \\
\cline { 2 - 4 } & Isotropic & Unidirectional \\
\cline { 2 - 4 } & Direction cannot be controlled & Direction is controlled (beam) \\
\hline \multirow{2}{*}{ Consequence } & $\begin{array}{l}\text { Non-stop operation (24/7) to } \\
\text { optimize source use }\end{array}$ & Flexible operation schedule \\
\hline
\end{tabular}




\section{Current Trends in Natural Sciences}

Vol. 9, Issue 18, pp. 100-106, 2020

https://doi.org/10.47068/ctns.2020.v9i18.014

Current Trends in Natural Sciences (on-line)

ISSN: 2284-953X

Current Trends in Natural Sciences (CD-Rom)

ISSN: 2284-9521

ISSN-L: 2284-9521

ISSN-L: 2284-9521

Gamma rays are high energy photons and they are produced by spontaneous disintegration of radionuclides ${ }^{60} \mathrm{Co}$ and ${ }^{137} \mathrm{Cs}$. A major characteristic of gamma rays is their high penetrating power, which facilitates their use in treatment of bulk items. The second source of ionizing radiation are accelerated electrons produced by electron accelerating machines known as electron accelerators. However, the depth of penetration of accelerated electrons is only 8 to $10 \mathrm{~cm}$ for typical food products, therefore the size of food products has to be considered before irradiation. The main advantage of electron accelerators is that they can be switched off when not in use. The third source are X-rays, produced by X machines. They carry the dual advantage of high penetration power and switch off capability. X-radiation penetrates foods more shallowly than gamma irradiation but much more deeply than electron beams (Pillai, 2004; Ahmad Shah et al., 2014).

The difference in characteristics of these types of ionizing radiation results in their different capabilities to penetrate into matter (Table 1).

Irradiation of food and agricultural commodities has been recognized as one of the most reliable and safest methods for preservation of food and agricultural commodities, for maintenance and improvement of hygienic quality and nutritional value, and has been used to overcome quarantine and trade-related barriers (Ahmad Shah et al., 2014).

Applications of food irradiation are usually organized into three categories according to the range of delivered dose (Table 2).

Table 2. Various dose levels of irradiation and their application (Ahmad Shah et al., 2014)

\begin{tabular}{|l|l|l|}
\hline \multicolumn{1}{|c|}{ Dose level } & \multicolumn{1}{c|}{ Purpose } & \multicolumn{1}{c|}{ Food items } \\
\hline $\begin{array}{l}\text { 1. Low Dose } \\
\text { (up to } 1 \text { kGy) }\end{array}$ & $\begin{array}{l}\text { Prevent sprouting (potatoes, onions, garlic etc) } \\
\text { Kill insects and larvae in wheat, flour, fruits and } \\
\text { vegetables after harvesting. } \\
\text { Slow ripening process. } \\
\text { Kill certain harmful parasites associated with foods. }\end{array}$ & $\begin{array}{l}\text { Potatoes, onions, garlic, ginger, } \\
\text { bananas, mangoes and other } \\
\text { non-citrus fruits, cereals and } \\
\text { pulses, dehydrated vegetables, } \\
\text { dried fish and meat, fresh pork. }\end{array}$ \\
\hline $\begin{array}{l}\text { 2. Medium Dose } \\
\text { Pasteurization }\end{array}$ & $\begin{array}{l}\text { Drastic reduction of the number or elimination of } \\
\text { certain microbes and parasites that cause food spoilage. } \\
\text { Reduction or elimination of many pathogenic } \\
\text { microorganisms. }\end{array}$ & $\begin{array}{l}\text { Strawberries, grape, dehydrated } \\
\text { vegetables, fresh or frozen } \\
\text { seafood, fish, raw or frozen } \\
\text { poultry and meat. }\end{array}$ \\
\hline $\begin{array}{l}\text { 3. High Dose } \\
\text { Sterilization } \\
(10-50 \text { kGy) }\end{array}$ & $\begin{array}{l}\text { Sterilization of food for special uses, such as meals for } \\
\text { immunocompromised patients. } \\
\text { Elimination of some disease causing viruses. }\end{array}$ & $\begin{array}{l}\text { Sterilized food for } \\
\text { immunocompromised patients. }\end{array}$ \\
\hline
\end{tabular}

1. Low-dose applications (<1kGy) - Racidation. Irradiation doses below $1 \mathrm{kGy}$ can be applied to prevent sprouting, slow ripening process, and extend fresh life of fruits and vegetables.

2. Medium-dose (1 - $10 \mathrm{kGy}$ ) applications - Radurisation. Irradiation doses in the range of 1 to $10 \mathrm{kGy}$ can be applied in: eradication or elimination of food borne pathogens, reducing food spoilage. The term implies pasteurization by irradiation.

3. High-dose (>10 KGy) applications - Radappertisation. Dose rates are usually in the range of $20-30 \mathrm{kGy}$ and they associated with radiation sterilization of foods. Food treated in this way can be stored and treated just like canned food (Miller, 2005).

Food irradiation has many advantages over the other food preservation methods. such us: heating, drying, and cooking. It provides an appropriate alternative to harmful chemical treatments, and are a 
suitable alternative to chemical fumigants which used for decontamination of spices and herbs and for disinfestations of insects in grains (Thayer and Rajkowski, 1999; Lima et al., 2018).

\section{EFFECTS OF IRRADIATION ON MICROBIOLOGICAL CONTAMINANTS OF FOODS}

The mechanism of microbial inactivation by ionizing radiation is based mainly on the principle of disruption of normal cellular activity through damaging the nucleic acids by "direct" and "indirect" effects (Pillai, 2004). The direct effect is caused by the removal of electrons as a result of energy deposition by ionizing radiation on target molecules, such as DNA (Erkmen and Bozoglu, 2016). In addition, damage to the nucleic acids can also occur when the radiation ionizes an adjacent molecule, which in turn reacts with the genetic material. Water is very often the adjacent molecule. Ionizing radiation causes water molecules to lose an electron, producing $\mathrm{H}_{2} \mathrm{O}^{+}$and $\mathrm{e}^{-}$. These products react with other water molecules to produce a number of compounds including hydrogen and hydroxyl radicals, molecular hydrogen, oxygen, and hydrogen peroxide These products in turn react with other water molecules, with nucleic acids, and with other biologically sensitive molecules. The most reactive by-products arising from the radiolysis of water are the hydroxyl radicals $(\cdot \mathrm{OH})$ and hydrogen peroxide $\left(\mathrm{H}_{2} \mathrm{O}_{2}\right)$. These products are highly reactive, and cause breakdown of single strand DNA at the sugar-phosphate bonds, as well as with the bonds that link the adjacent base pair to an opposite strand in double strand DNA (Pillai, 2004; Sádecká, 2007; Erkmen and Bozoglu, 2016).

The principal targets of irradiation are nucleic acids and cell membrane lipids. Ionizing radiation causes damage to the cell membrane and other structures (sublethal injury). Alteration in membrane lipids, particularly polyunsaturated fatty acids, leads to perturbation of membranes and effects on various membrane functions, such as permeability. The activity of membrane enzymes may also be affected (Erkmen and Bozoglu, 2016).

In living cells, e.g., yeasts, molds and bacteria, the irradiation effects are manifest through the induction of genomic, biochemical, physiological and morphogenetic changes. Many factors play an important role in the inactivation of microorganisms by irradiations. Some of them are: type of radiation, species of microorganisms, composition of foods, oxygen content, physical state of foods, physiological state of microorganisms (Pillai, 2004; Erkmen and Bozoglu, 2016).

The major food spoilage microorganisms and many common foodborne pathogens of different species are generally sensitive to irradiation and can be inactivated by low and medium doses of radiation between 1 and $7 \mathrm{kGy}$. Molds are more sensitive to irradiation than yeasts, yeasts are more sensitive to irradiation than bacteria, and bacteria are more sensitive to irradiation than viruses (Erkmen and Bozoglu, 2016).

Gram-positive bacteria are more resistant to irradiation than Gram-negative, and cocci are more resistant than rods at same irradiation dose. The structure of cell wall play an important role in bacterial resistance (Lung et al., 2016). The irradiation sensitivity can be different in different strains and isolates of the same species of bacteria (Xu et al., 2019). The resistance to irradiation of microorganisms may increase as a result of their adaptation to the stress conditions. Certain resistance genes to specific antibiotics may help some of the pathogenic bacteria to tolerate higher doses of irradiation (Gaougaou et al., 2018; Skowron et al., 2018).

Also, sensitivity of bacteria to irradiation, depends upon the growth phase. In general, the cells in the exponential growth phase are more sensitive to ionizing radiation than microbial populations in the latent or stationary phase. This may be due to the fact that many of genes expressed during the 
stationary phase are required for starvation survival, and they encode proteins with specific roles in the protection of the cell against external stresses (heat, oxidants, osmotic challenge and exposure to toxic chemicals). This is known as stasis-induced cross-protection, and relies largely on the stationary phase $\sigma^{\mathrm{s}}$ factor (RpoS), which controls expression of over 50 genes (Sukhi et al., 2009). However, study on high radiation resistant bacteria Deinococcus radiodurans has shown that their late stationary phase cells are more sensitive to irradiation compared with exponential or early stationary phase cells. Analysis of genome sequence of $D$. radiodurans evidently have shown that some of sigma factor genes, including rpoS gene, encoding stationary phase $\sigma^{\mathrm{s}}$ factor are missed. This indicate that stress response mechanisms in this very radiation resistant bacteria differ from established patterns (Hastings et al., 1986; Mendonca et al., 2004; Sukhi et al., 2009).

\section{EFFECTS OF IRRADIATION ON FOOD COMPONENTS}

The effect of irradiation on food components depends on the dose of irradiation used, the food matrix and preparation method. In fact, heating, drying, and cooking may cause higher nutritional losses. Moreover, certain carcinogenic aromatic and heterocyclic ring compounds produced during thermal processing of food at high temperatures are not identified in food after irradiation (Sádecká, 2007).

According to experimental evidence and literature date, food macronutrients (carbohydrates, proteins, and lipids) and most micronutrients (mainly water soluble and fat-soluble vitamins) are not appreciably affected by low and medium range ionizing doses (up to10 kGy) with regard to their nutrient contents. Ionizing irradiation is one of the food preservation techniques with minimum interruption of to the functional, nutritional, and sensory properties of food products at lower doses. However, high-dose irradiation, especially higher than $10 \mathrm{kGy}$, can lead to physicochemical changes and significantly deteriorate sensory properties of foods (Miller, 2005; Kim et al., 2006).

At higher radiation doses (above $10 \mathrm{kGy}$ ), the structural properties of the fibrous carbohydrates can be degraded (Crawford and Ruff, 1996; Miller, 2005; Dionísio et al., 2009).

The effect of irradiation (low and medium doses), on the nutritional content of lipids is minimal. In fact, such doses will not cause the formation of aromatic or heterocyclic rings, or the condensation of aromatic rings, all of which are considered to be carcinogenic, and it is known to be formed at high cooking temperatures. However, the irradiation of lipids at high doses, and especially in the presence of oxygen, can lead to the formation of liquid hydroperoxides. While not necessarily harmful, these substances often have undesirable odors and flavors (rancidity). The unsaturated fatty acids are more prone to develop rancidity. Lipid oxidation can be significantly reduced by freezing, and/or by oxygen removal prior to irradiation (Miller, 2005).

In the study of effect of irradiation on the fatty acid profile of irradiated beef meat, Stefanova et al., 2011 reported a dose-dependent changes in fatty acid composition. Performed NMR and GC analyses in the study reveal an increase in the amount of saturated fatty acids and a decrease in the amount of polyunsaturated fatty acids in the irradiated beef samples compared with the unirradiated one, established with increase of the irradiation dose.

In fat-containing food ionizing radiation induces formation of volatile hydrocarbons and 2alkylcyclobutanones (2-ACBs), which are radiolytic derivatives of triglycerides. They are generated proportionally to fat content and absorbed radiation dose. 2-ACBs are formed in food only by irradiation, and therefore they are considered as useful markers for detecting the irradiation of food (Kim et al., 2004a; Kim et al., 2004b; Obana et al., 2006). 
Vitamins can be susceptible and sensitive to any processing technique (Woodside, 2015). Concering food irradiation, some vitamins such as riboflavin (B2), pyridoxine (B6) and biotin are usually stable, others such as thiamin (B1) and vitamins A, C and E are relatively labile. Thiamin and vitamin $\mathrm{C}$ are the most radiation-sensitive vitamins. The sensitivity of vitamin $\mathrm{C}$ is in relation to several factors, such us: exposure to oxygen, temperature elevation, $\mathrm{pH}$ modifications (Dionísio et al., 2009).

\section{CONCLUSIONS}

The use of ionizing radiation to destroy harmful biological organisms in food, is a safe, proven techniques that has many useful applications. It has been endorsed by numerous health organizations and has now been approved for many applications by governments around the world. Food irradiation offers a potential to enhance microbiological safety and quality of food through shelf-life extension. It is considered a more effective and appropriate method to enhance food stability and safety, when compared to other processing methods like heat and chemical methods. Also, it does not reduce significantly the nutritional and the sensory quality of food.

\section{ACKNOWLEDGEMENTS}

The authors express the gratitude to IAEA for scientific visit grants in frame of the IAEA TC Project - MAK 5007.

\section{REFERENCES}

Ahmad Shah, M., Ahmad Mir, S., Ahmad Pala, S. (2014). Enhancing food safety and stability through irradiation: A review. Journal of Microbiology, Biotechnology and Food Sciences 3 (5), 371-378.

Codex Alimentarius., FAO/WHO., General Standard for Irradiated Foods. (2003). CODEX STAN 106-1983, Rev.12003, Codex Alimentarius Commission, Rome.

Crawford, L.M., Ruff, E.H. (1996). A review of the safety of cold pasteurization through irradiation. Food Control, 7 , 87-97.

Dionísio, A.P., Gomes, R.T., Oetterer, M. (2009). Ionizing radiation effects on food vitamins: A review. Brazilian Archives of Biology and Technology, 52, 1267-1278.

Erkmen, O., Bozoglu, F. (2016). Food Preservation by Irradiation. In: Food Microbiology: Principles into Practice. First Edition, (Vol. 2, pp. 106-127), John Wiley \& Sons, Ltd. Published. Oxford.

Farkas, J. (1998). Irradiation as a method for decontaminating food. A review. International Journal of Food Microbiology, 44, 189-204.

Farkas, J. (2006). Irradiation for Better Foods. Trends in Food Science \& Technology, 17, 148-152.

Farkas, J., Mohacs -Farkas, C. (2011). History and future of food irradiation. Trends in Food Science \& Technology, 22, $1-6$.

Gaougaou, G., Ben-Fadhel, Y., Déziel, E., Lacroix, M. (2018). Effect of $\beta$-lactam antibiotic resistance gene expression on the radio-resistance profile of E. coli O157:H7. Heliyon, 4, e00999.

Hastings, J.W., Holzapfel, W.H., Niemand, J.G. (1986). Radiation resistance of lactobacilli isolated from radurized meat relative to growth and environment. Applied Environmental Microbiology, 52, 898-901.

International Atomic Energy Agency. (2015). Manual of good practice in food irradiation: Sanitary, phytosanitary and other applications. Technical Reports Series No. 481, IAEA. Viena.

Junqueira-Goncalves, M.P., Galotto, M.J., Valenzuela, X., Dinten, C.M., Aguirre, P., Miltz, J. (2011). Perception and view of consumers on food irradiation and the radura symbol. Radiation Physics Chemistry, 80, 119-122.

Kim, K.S., Seo, H.Y., Lee, J.M., Park, E.R., Kim, J.H., Hong, C.H., Byun, M.W. (2004a). Analysis of radiation-induced hydrocarbons and 2-alkylcyclobutanones from dried shrimps (Penaeus aztecus). Journal of Food Protection, 67, $142-147$.

Kim, J.H., Seo, H.Y., Kim, K.S. (2004b). Analysis of radiolytic products of lipid in irradiated dried squids (Todarodes pacificus). Journal of Food Protection, 67, 1731-1735. 


\section{Current Trends in Natural Sciences}

Vol. 9, Issue 18, pp. 100-106, 2020

https://doi.org/10.47068/ctns.2020.v9i18.014

Current Trends in Natural Sciences (on-line)

ISSN: 2284-953X

Current Trends in Natural Sciences (CD-Rom)

ISSN: 2284-9521

ISSN-L: 2284-9521

ISSN-L: 2284-9521

Kim, M.J., Park, J.G., Kim, J.H., Park, J.N., Lee, H.J., Kim, W.G., Lee, J.W., Byun, M.W. (2006). Combined effect of heat treatment and gamma irradiation on the shelf- stability and quality of packaged Kimchi during accelerated storage condition. Korean Journal of Food Preservation, 13, 531-537.

Kobayashi, Y. (2018). Food Irradiation: Radiation-Based Sterilization, Insecticidal, and Inhibition of Sprouting Technologies for Foods and Agricultural Produce. In H. Kudo, eds, Radiation Applications, An Advanced Course in Nuclear Engineering (Vol. 7, pp. 217-253). Springer, Singapore.

Lima, F., Vieira, K., Santos, M., Mendes de Souza, P. (2018). Effects of radiation technologies on food nutritional quality. In V.A Dia, M.A. Gracia-Gimeno, eds, Descriptive Food Science pp. 137-152. IntechOpen Limited, London.

Lung, H.M., Cheng, Y.C., Chang, Y.H., Huang, H.W., Yang, B.B., Wang, C.Y. (2015). Microbial decontamination of food by electron beam irradiation. Trends in Food Science and Technology, 44, 66-78.

Mendonca, A.F., Romero, M.G., Lihono, M.A., Nannapaneni, R., Johnson, M.G. (2004). Radiation resistance and virulence of Listeria monocytogenes Scott a following starvation in physiological saline. Journal of Food Protection, 67, 470-474.

Miller, R.B. (2005). Electronic Irradiation of Foods: An Introduction to the Technology. Springer, New York.

Mostafavi, H.A., Fathollahi, H. Motamedi, F., Mirmajlessi, S. M. (2010)., Food irradiation: Applications, public acceptance and global trade: A review. African Journal of Biotechnology, 9 (20), 2826-2833.

Mostafavi, H.A., Mirmajlessi, S.M., Fathollahi, H. (2012). The potential of food irradiation: Benefits and limitations. In A.A. Eissa, eds,. Trends in Vital Food and Control Engineering. 43-68. IntechOpen Limited, London.

Molins, R. (2001). Food Irradiation: Principles and Application. John Wiley \& Sons, Inc, New York.

Obana, H.; Furuta, M.; Tanaka, Y. (2006). Detection of 2-alkylcyclobutanones in irradiated meat, poultry and egg after cooking. Journal of Health Science, 52, 375-382.

Pillai, S.D. (2004). Food Irradiation. In Ross et al., eds, Preharvest and Postharvest Food Safety: Contemporary Issues and Future Directions, Blackwell Publishing and the Institute of Food Technologists, Iowa.

Rahman, M.S. (2012). Food preservation and processing methods. In: Ahmed J., Rahman M.S eds, Handbook of Food Process Design. Blackwell Publishing, New York,

Sadecka, J. (2007). Irradiation of Spices - A Review. Czech Journal of Food Sciences, 25, 231-242.

Skowron, K., Grudlewska, K., Gryn, G.; Skowron, K.J., Swieca, A., Paluszak, Z., Zimek, Z., Rafalski, A., GospodarekKomkowska E. (2018). Effect of electron beam and gamma radiation on drug-susceptible and drug-resistant Listeria monocytogenes strains in salmon under different temperature. Journal of Applied Microbiology, 125, $828-842$.

Stefanova, R., Toshkov, S., Vasilev, N.V., Vassilev, N.G., Marekov, I.N. (2011). Effect of gamma-ray irradiation on the fatty acid profile of irradiated beef meat. Food Chemistry, 127, 461-466.

Sukhi, S.S., Shashidhar, R., Kumar, S.A., Bandekar, J.R. (2009). Radiation resistance of Deinococcus radiodurans R1 with respect to growth phase. FEMS Microbiology Letters, 297, 49-53.

Xu, A., Scullen, O.J., Sheen, S., Johnson, J.R., Sommers, C.H. (2019). Inactivation of extraintestinal pathogenic E. coli clinical and food isolates suspended in ground chicken meat by gamma radiation. Food Microbiology. 84, 103264.

Thayer, D.W., Rajkowski, K.T. (1999). Development in irradiation of fresh fruits and vegetables. Journal of Food Technology, 53 (11), 62-65.

Woodside, J.V. (2015). Nutritional aspects of irradiated food. Stewart Postharvest Review, 3 (2), 1-6. 